\title{
Pre-Operative Evaluation of the Internal Thoracic Artery from the Morphology of Thorax and Morphotypia: Preliminary Study M Gaye $^{1,2 *}$, S Diop ${ }^{2}$, P A Diagne ${ }^{2}$, R Wade ${ }^{1}$, Ai Ndiaye ${ }^{1}$, S Diatta ${ }^{2}$, PS Ba ${ }^{2}$, PA Dieng ${ }^{2}$, AG Ciss ${ }^{2}$, As Ndiaye ${ }^{3}$ Ab Ndiaye $^{1}$
}

\footnotetext{
${ }^{1}$ Laboratory of Anatomy and Organogenesis, Faculty of Medicine, Pharmacy and Dentistry, University of Cheikh Anta Diop, Dakar (Senegal)

${ }^{2}$ Department of Thoracic and Cardiovascular Surgery, Fann Hospital, Dakar (Senegal)

${ }^{3}$ Laboratory of Anatomy and Organogenesis, Training and research Unit of Medical science, University of Assane Seck, Ziguinchor (Senegal)
}

DOI: $10.36347 /$ sasjs.2020.v06i05.002

| Received: 02.05.2020 | Accepted: 09.05.2020 | Published: 12.05.2020

*Corresponding author: Magaye GAYE

\section{Abstract}

Original Research Article

The internal thoracic artery (ITA) is the graft of choice in coronary bypass surgery, despite insufficient means for its pre-operative evaluation. Therefore, we propose an alternative based on statistical correlation. From 23 anatomical adults fresh subjects, we evaluated the morphotypia and measured diameters and length of the ITA. The correlations show a relationship between the morphotypia and the length of the ITA and that between the circumference of the thorax and the diameter of the ITA. Therefore, the clinical exam will provide an idea of the ITA's quality using a mathematical formula.

Keywords: ITA, chest circumference, ITA length, morphotypia, ITA diameter.

Copyright @ 2020: This is an open-access article distributed under the terms of the Creative Commons Attribution license which permits unrestricted use, distribution, and reproduction in any medium for non-commercial use (NonCommercial, or CC-BY-NC) provided the original author and source are credited.

\section{INTRODUCTION}

As part of the preoperative assessment of coronary artery bypass surgery, a step is devoted to the study of the quality of the graft. The exploration of the internal thoracic artery was preferably done by angiography, after catheterization of the artery. This exploration made it possible to have a complete cartography thus showing possible anatomical variations and pathologies $[1,2]$.

Doppler ultrasound remained the choice for flow measurement, both before and after bypass of the ITA on a coronary artery [3-6]. It was also recommended, for the morphological study, in the event of contraindication to an angiography [7].

We propose an appreciation of the length and the diameter of the ITA from a correlation with fixed marks of the thoracic wall.

\section{MATERIAL AND METHODS}

To carry out this work, we had dissected 46 internal thoracic arteries including 23 right and 23 left on 23 fresh adult anatomical subjects composed of 3 women and 20 men presenting no traumatism or thoracic deformation.
This study was carried out simultaneously at the pathological anatomy departments of the Aristide Le Dantec (HALD) and General de Grand Yoff (HOGGY) hospitals.

To carry out this work, we used:

- a common dissection box with a costotome;

- a tape measure;

- a compass;

- a digital camera;

- a computer

- Epi-Info software version 3.3.2, for statistical analyzes.

On the subject, installed in supine position, we noted the morphotypy and measured the circumference of the thorax at the height of the middle of the line connecting the acromion to the lateral epicondyle of the humerus as well as the height of the thorax at the midlevel clavicular.

The morphotype was defined relative to the angle formed by the two cost edges. If this angle is greater than $30^{\circ}$, the subject was said to be Brevilic and if this angle is less than $30^{\circ}$, it was said to be Longilic. 
The approach was a mid-thoracic-abdominal incision from the sternal jugular notch to the pubis. The anterior musculo-cutaneous wall of the thorax was completely detached from the rib grill to the left and right middle rib arches. The rectus abdominis muscles were cut transversely in addition to the umbilical, to facilitate the recline of the musculo-cutaneous wall of the thorax and thus improve the exposure of the sternocostal bib.

The ribs were sectioned at the level of the anterior arches from $\mathrm{K} 1$ to $\mathrm{K} 7$ and a sternoclavicular disarticulation was performed on both sides.

The breastbone was also separated from the pleura, pericardium and other elements of the mediastinum, while avoiding damage to the internal thoracic arteries.

After section of its attachments, the sternocostal bib was lifted from bottom to top which allowed to visualize its posterior face.
The ITA were visualized after separation of the latter with the cellulo-fatty tissue of the posterior surface of the sterno-costal bib and section of the transverse muscles of the right and left sternum.

After opening of the vascular sheath and separation from the internal thoracic veins; the dissection of the ITA was done, starting at the level of the sternal manubrium, by a gentle traction. This dissection was continued, distally, by the section and the reclinement of the transverse muscle of the sternum. Thus, still by gentle traction, the ITA was separated from its satellite veins until it branched off.

This dissection allowed us to note:

- the total length of the ITA;

- the external diameter of the original ITA;

- the external diameter of the ITA at costal levels from $\mathrm{K} 1$ to $\mathrm{K} 6$.

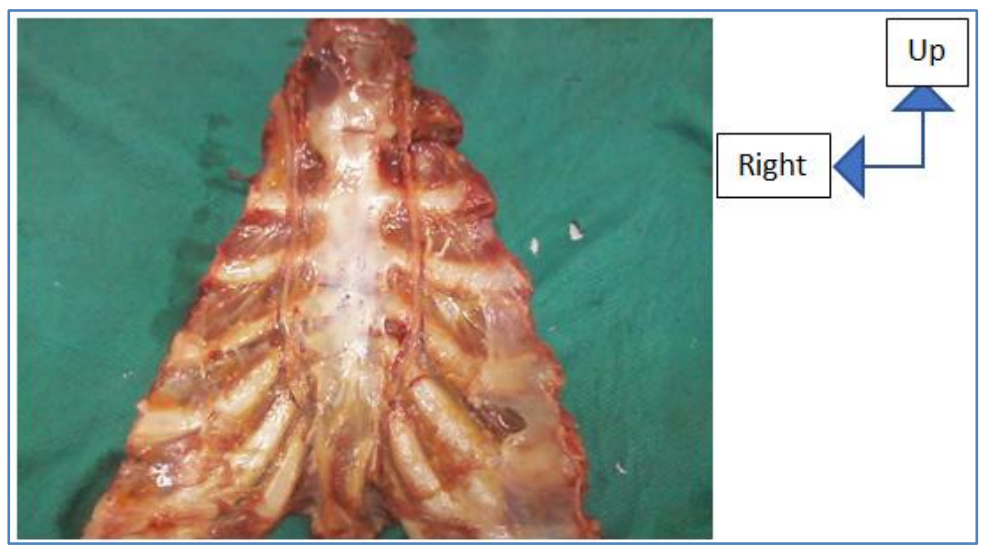

Fig-1: Plastron sterno-costal: fascia endothoracique disséqué

\section{RESULTS}

Morphotypia

The brief morphotype was found in 16 subjects and the long one in 07 subjects; which corresponded to respective percentages of $69.6 \%$ and $30.4 \%$.

\section{Measurements of the thorax}

The average chest circumference was $71 \mathrm{~cm}$ while the minimum was $44 \mathrm{~cm}$ and the maximum 92 $\mathrm{cm}$.

\section{ITA length}

The average total length of the ITA was 171.7 and $172.4 \mathrm{~mm}$ respectively on the right and on the left. The extreme lengths were 120 and $260 \mathrm{~mm}$, on both sides. The most common lengths were $150 \mathrm{~mm}$ on the right and $145 \mathrm{~mm}$ on the left.
In 04 cases the exact length of the artery could not be determined, due to its continuity with the lower epigastric artery.

\section{ATI diameters \\ Origin}

The diameters at the origin of the right and left internal thoracic arteries were on average $3.1 \mathrm{~mm}$ with a smaller diameter at $2 \mathrm{~mm}$ and a larger diameter at 5 $\mathrm{mm}$. The most frequently encountered diameter was $3 \mathrm{~mm}$.

\section{At the trunk level}

At the right rib levels, from $\mathrm{K} 1$ to $\mathrm{K} 6$, the average diameters varied between 2.6 and $3.05 \mathrm{~mm}$ while on the left, they were between 2.6 and $2.9 \mathrm{~mm}$. The most frequent diameter was $3 \mathrm{~mm}$ (Tables I and II). 
Table-I: Variations in diameter of the right ITA according to costal levels from K1 to K6

\begin{tabular}{|l|l|l|l|}
\hline Costal levels & $\begin{array}{l}\text { Mean } \\
\text { Diameters }(\mathbf{m m})\end{array}$ & $\begin{array}{l}\text { Minimal } \\
\text { diameters }(\mathbf{m m})\end{array}$ & $\begin{array}{l}\text { Maximal } \\
\text { diameters }(\mathbf{m m})\end{array}$ \\
\hline $\mathrm{K} 1$ & 2 & 5 \\
\hline $\mathrm{K} 2$ & 3,05 & 2 & 5 \\
\hline $\mathrm{K} 3$ & 3,05 & 2 & 5 \\
\hline $\mathrm{K} 4$ & 3,01 & 2 & 5 \\
\hline $\mathrm{K} 5$ & 2,96 & 1 & 4 \\
\hline $\mathrm{K} 6$ & 2,79 & 1 & 4 \\
\hline
\end{tabular}

Table-II: Variations in diameter of the right ITA according to costal levels from K1 to K6

\begin{tabular}{|l|l|l|l|}
\hline Costal levels & $\begin{array}{l}\text { Mean } \\
\text { diameters }(\mathbf{m m})\end{array}$ & $\begin{array}{l}\text { Minimal } \\
\text { diameters }(\mathbf{m m})\end{array}$ & $\begin{array}{l}\text { Maximal } \\
\text { diameters }(\mathbf{m m})\end{array}$ \\
\hline $\mathrm{K} 1$ & 2,87 & 0,3 & 5 \\
\hline $\mathrm{K} 2$ & 2,99 & 2 & 5 \\
\hline $\mathrm{K} 3$ & 2,96 & 2 & 5 \\
\hline $\mathrm{K} 4$ & 2,92 & 2 & 5 \\
\hline $\mathrm{K} 5$ & 2,72 & 1 & 4 \\
\hline $\mathrm{K} 6$ & 2,66 & 1 & 4 \\
\hline
\end{tabular}

\section{Correlation and comparison (table III)}

We compared and correlated, by statistical tests, the average length and diameter of the ITA with other parameters.

\section{The average length of the ITA}

\section{According to the morphotype}

A simple bilateral Student test is performed with a significance level of 5\%. Crosses between the morphotype and the average lengths of the right and left ITA showed a $\mathrm{p}$ value of 0.03005 and 0.01717 respectively. This result means that the lengths of the right and left ITA are longer, in longilic, with a statistically significant difference.

\section{According to the circumference of the thorax}

A Pearson linear correlation, between the circumference of the thorax and the total lengths of the right and left ITA, is made. The $\mathrm{p}$ values are less than $5 \%$ and the absolute values of the correlation coefficients are less than 1 . These results show that there is no link and no correlation between the circumference of the thorax and the total length of the ITA.

Depending on the height of the chest

Pearson's linear correlation test shows that there is no link and correlation between the height of the chest and the total length of the ITA.

\section{According to the height of the sternum}

According to the Pearson test, the $\mathrm{p}$ value is less than $5 \%$ and the correlation coefficient is close to 1. Thus there is a link and a correlation between the height of the sternum and the total length of the ITA; but it's not linear.

Between the circumference of the thorax and the diameter of the ITA

This correlation with the same Pearson test gives as a result a p value of 0.00695 and a correlation coefficient of 0.5466808 . This result means that there is a link and a correlation between the circumference of the thorax and the diameter of the ITA.

Table-III: Correlation and link between some quantitative variables

\begin{tabular}{|l|l|l|l|}
\hline correlation & P value & Correlation coefficient & Interpretation \\
\hline Chest circumference and total length of right ITA & 0,368 & $-0,1968542$ & $\begin{array}{l}\text { - No link } \\
\text { - No correlation }\end{array}$ \\
\hline Chest circumference and total length of the left ITA & 0,59 & $-0,1185709$ & $\begin{array}{l}\text { - No link } \\
\text { - No correlation }\end{array}$ \\
\hline Chest height and right ITA length & 0,09586 & $-0,3556043$ & $\begin{array}{l}\text { - No link } \\
\text { - No correlation }\end{array}$ \\
\hline Height of chest and length of left ITA & & & $\begin{array}{l}\text { - No link } \\
\text { - No correlation }\end{array}$ \\
\hline Height of sternum and total length of right ITA & 0,09178 & $-0,3597541$ & $\begin{array}{l}\text {-Existence of a link } \\
\text {-Existence of correlation }\end{array}$ \\
\hline Height of the sternum and total length of the left ITA & 0,02465 & 0,4670292 & $\begin{array}{l}\text {-Existence of a link } \\
\text {-Existence of correlation }\end{array}$ \\
\hline Chest circumference and right ITA diameter & 0,0505 & 0,4124344 & $\begin{array}{l}\text {-Existence of a link } \\
\text {-Existence of correlation }\end{array}$ \\
\hline Chest circumference and left ITA diameter & 0,00695 & 0,5466808 & $\begin{array}{l}\text {-Existence of a link } \\
\text {-Existence of correlation }\end{array}$ \\
\hline
\end{tabular}




\section{DISCUSSION}

Knowledge of the course and quality of the internal thoracic artery has always preoccupied cardiac surgeons since the discovery of the efficiency of this artery as a graft in coronary bypass surgery. This internal thoracic artery has several qualities in comparison to other arterial and venous grafts. The ITA is the only peripheral artery in the human body that is elastic, being composed of an intima that is lim- ited by a well-formed internal elastic lamina and a media that is formed by a network of circularly and longitudinally interlacing elastic lamellae between which smooth muscle cells are dispersed in a spiral fashion [8].

The endothelium of the ITA is itself unique with a sig- nificantly higher basal production of vasodilators such as nitric oxide and prostacyclin. The ITA demonstrates a favorable response to the pharmacological agents commonly used in the postoperative period $[9,10]$. Although the difference in endothelial-derived relaxation factors among the arterial conduits (ITA, radial, and inferior epigastric arteries) is less, the difference between the ITA and saphenous vein is marked [11]. The ITA dilates in response to milrinone and nitrogly- cerine [12, 13]. It does not constrict in response to nor- adrenaline $[12,13]$. The endogenous secretion of vasodilators may also have a downstream effect on the coronary vasculature, explaining the common observation that the coronary target itself appears relatively protected distal to the anastomosis. The important cause of ITA spasm is thromboxane secretion due to injury during ITA harvest and preparation of the graft [14]. Papaverine, a shortacting phospho-diesterase inhibitor, is a widely used vasodilator to treat vasospasm of the ITA. The ITA pedicle is sprayed with papaverine solution or wrapped in papaverine- soaked gauze. The intraluminal injection of papaverine may cause endothelial injury $[15,16]$.

Despite these many advantages, the fear of the cardiac surgeon is to locate the internal thoracic artery but also to have a good caliber artery with a correct length in order to allow correct anastomoses. Indeed, the only means of $100 \%$ sensitive exploration allowing to have an idea of the caliber and the course of this artery is angiography. The latter is expensive and invasive. This is how Lee[17] provided a precise landmark with which to locate the internal mammary vessels, using the "1-2-3 rule." Lee et al. found that the vessels were located medially to the costochondral junctions at 12.80, 24.78, and $33.28 \mathrm{~mm}$ at costal levels 2,3 , and 4, respectively [17]. The authors' proposed 12-3 rule easily depicts the mean distances between the costochondral junctions and internal mammary arteries to be 1,2 , and $3 \mathrm{~cm}$, with a deviation of $5 \mathrm{~mm}$ at costal levels 2,3 , and 4 [17].

On the other hand, demonstrates that this rule does not apply to longilic subjects. Note that Lee carried out his study on an Asian population, therefore small.
Our work is part of this same remote appreciation register of the thoracic artery. Indeed, our correlations between the diameter of the internal thoracic artery and the largest circumference of the thorax, on one side, and the morphology and length of the artery, on the other hand, will allow us to evolve towards formulas to calculate the length and diameter of the ITA.

\section{CONCLUSION}

ITA has generated a lot of interest in bypass surgery. The only current constraint remains its preoperative evaluation which remains almost impossible. Our correlations constitute a springboard to evolve towards a calculation of the length and the gauge in preoperation.

\section{Authorization of the ethics comittee}

The Ethics Committee of the Faculty of Medicine and Odontotology of Dakar gave us its agreement for the realization of this study.

\section{CONFLICTS OF INTEREST}

The authors of this article declare that there is no conflict of interests.

\section{REFERENCES}

1. Korkuk AK, Cetin G, Suzer K. Internal thoracic artery as a main blood supply to the lower limbs. Case report. Acta Chir Belg. 2006 MarApr;106(2):243-247.

2. Peric M, Sagic D, Miric M, Bojic M. Angiographic characteristics of the internal thoracic artery: anatomic variations and their surgical importance. Med Pregl. 2000 May-Jun;53(5-6):245-253.

3. Cagli K, Emir M, Kunt A and al. Evaluation of the flow characteristics of the left thoracic artery graft perioperative color Doppler ultrasonography versus intraoperative free bleeding technique. Texas Heart Institute Journal. 2004;31(4)376-381.

4. Lobo Filho JG, Leitão MC, Forte AJ, Lobo Filho HG, Silva AA, Bastos ES, Murad H. Flow analysis of left internal thoracic artery in myocardial revascularization surgery using $\mathrm{Y}$ graft. Texas Heart Institute Journal. 2006;33(4):430.

5. Mannacio V, Di Tommaso L, De Amicis V, Stassano P, Vosa C. Randomized flow capacity comparison of skeletonized and pedicled left internal mammary artery. The Annals of thoracic surgery. 2011 Jan 1;91(1):24-30.

6. Pavy B, Tisseau A. Exploration ultrasonographique des pontages mammaires internes gauches: intérêt et limites en réadaptation cardiaque. InAnnales de cardiologie et d'angeiologie 2009 Nov 1 (Vol. 58, No. 5, pp. 258-264). Elsevier Masson.

7. Jonsson K, Karlsson S. Angiography of the internal mammary artery. Acta Radiol Diagn. 1985 MarApr;26():113-120.

8. van Son JA, Smedts F, Vincent JG, van Lier HJ and Kubat K. Comparative anatomic studies of 
various arter- ial conduits for myocardial revascularization. J Thorac Cardiovasc Surg. 1990; 99: 703-707.

9. Broeders MA, Doevendans PA, Maessen JG, van Gorsel E, Egbrink MG, Daemen MJ, Tangelder GJ, Reneman RS, van der Zee R. The human internal thoracic artery releases more nitric oxide in response to vascular endothelial growth factor than the human saphenous vein. The Journal of thoracic and cardiovascular surgery. 2001 Aug 1;122(2):305-9.

10. Sala A, Rona P, Pompilio G, Parolari A, Antona C, Biglioli P, Rossoni G, Villa LM, Berti F. Prostacyclin production by different human grafts employed in coronary operations. The Annals of thoracic surgery. 1994 May 1;57(5):1147-50.

11. Lüscher TF, Diederich D, Siebenmann R, Lehmann K, Stulz P, Segesser LV, Yang Z, Turina M, Grädel E, Weber E, Bühler FR. Difference between endothelium-dependent relaxation in arterial and in venous coronary bypass grafts. New England Journal of Medicine. 1988 Aug 25;319(8):462-7.

12. Gitter R, Anderson JM Jr and Jett GK. Influence of milrinone and norepinephrine on blood flow in canine internal mammary artery grafts. Ann Thorac Surg. 1996; 61: 1367-1371.

13. Jett GK, Arcici JM Jr, Hatcher CR Jr, Abel PW and Guyton RA. Vasodilator drug effects on internal mam- mary artery and saphenous vein grafts. J Am Coll Cardiol. 1988; 11: 1317-1324.

14. Cooper GJ, Wilkinson GA and Angelini GD. Overcoming perioperative spasm of the internal mam- mary artery: which is the best vasodilator? J Thorac Cardiovasc Surg. 1992; 104: 465-468.

15. Sasson L, Cohen AJ, Hauptman E and Schachner A. Effect of topical vasodilators on internal mammary arteries. Ann Thorac Surg. 1995; 59: 494-496.

16. He GW, Buxton BF, Rosenfeldt FL, Angus JA and Tatoulis J. Pharmacologic dilatation of the internal mam- mary artery during coronary bypass grafting. J Thorac Cardiovasc Surg. 1994; 107: 1440-1444.

17. Lee CD, Butterworth J, Stephens RE, Wright B, Surek C. Location of the internal mammary vessels for microvascu- lar autologous breast reconstruction: The "1-2-3 rule." Plast Reconstr Surg. 2018;142:28-36. 